\title{
Between a Rock and a Hard Place: Ecuador During the COVID-19 PANDEMIC
}

\author{
Entre la Espada y la Pared: Ecuador durante la pandemia de \\ COVID-19
}

\section{ANA SOFÍA CASTELLANOS SANTAMARÍA}

Portland State University, United States

\author{
RÉGIS DANDOY \\ Universidad San Francisco de Quito, Ecuador
}

\section{SEBASTIÁN UMPIERREZ DE REGUERO}

European University Institute, Italy E Universidad Diego Portales, Chile

\begin{abstract}
In 2020, Ecuadorian politics was not only constrained by the COVID-19 pandemic, but also stirred by political instability and an intense online electoral campaign. In this article, we outline the Ecuadorian economic, social, and political context from February 2020 to February 2021. Then, we explore the core measures and overall impacts of the COVID-19 on Ecuadorian politics. We also present the main institutional and policy changes, bearing in mind that 2020 was the last year of Lenín Moreno's presidential term. In addition, this article examines the latest electoral reform and the main issues of the electoral campaign, as well as the key results of the national and Andean elections of February 2021.
\end{abstract}

Keywords: COVID-19, Lenín Moreno, general elections, political instability, Ecuador.

\section{RESUMEN}

En 2020, la política ecuatoriana no solo se vio constreñida por la pandemia de COVID-19, sino también por la inestabilidad política y una intensa campaña electoral virtual. En este artículo, describimos el contexto económico, social y político ecuatoriano desde febrero de 2020 hasta febrero de 2021. Luego, exploramos las medidas centrales y los impactos generales del COVID-19 en la política ecuatoriana. Presentamos también los principales cambios institucionales y de política pública, considerando que 2020 fue el último año del mandato presidencial de Lenín Moreno. Adicionalmente, este artículo analiza la última reforma electoral y los principales temas de la campaña electoral, así como algunos resultados de las elecciones nacionales y andinas de febrero de 2021.

Palabras clave: COVID-19, Lenín Moreno, elecciones generales, inestabilidad politica, Ecuador. 


\section{INTRODUCTION}

After the public split between Rafael Correa and Lenín Moreno (Wolff 2018) and the intensive days of social mobilization in October 2019 against austerity measures (Altmann 2020; Olivares and Medina 2020), Moreno's administration faced a third major challenge: the COVID-19 pandemic. From late February 2020 onwards, the sanitary crisis in Ecuador has been a constant, affecting not only the quality of democracy (Edgell et al. 2020) and presidential approval (Informa Ecuador 2021), but also macroeconomic and social indicators (BCE 2020; INEC 2021). Overall, Moreno's government lacked understanding of the Ecuadorian democratic system and its institutional dynamics, in the wake of organized pressure and a national emergency such as the COVID-19 pandemic.

In a country where the sanitary crisis has had a significant impact on every corner of public life, including politics, this article explores the institutional changes, and the 2021 general elections. In Ecuador, these elections were crucial as they could reverse the path that Moreno's government adopted by politically distancing from Correa and his ideology. We dive deeper into the outcomes of the last year of Moreno's presidential term by focusing on its three main features: the political instability observed in the cabinet, the inter- and intra-coordination problems to mitigate the sanitary crisis, and the first round of the electoral cycle.

In what it follows, we outline the Ecuadorian economic, social, and political context from February 2020 to February 2021. Then, we explore the core measures and overall impacts of the COVID-19 on Ecuadorian politics. Thereafter, we briefly analyze the institutional and policy changes, considering that 2020 was the last year of Lenín Moreno's presidential term. Prior to our conclusion, we examine the latest electoral reform, and the main issues of the electoral campaign, as well as the key results of the national and Andean elections of February 2021.

\section{GENERAL OVERVIEW OF ECUADOR IN 2020}

\section{Economic context}

Given in part the temporary rise of oil prices ${ }^{1}$ between the end of 2019 and first trimester of 2020, Ecuador's economy slightly grew (see Figure 1). Yet, with the pandemic and an overall drop of oil prices in mid-2020, the real GDP growth was negative the entire year (BCE 2020). Prior to the sanitary crisis, Moreno promised to reduce public spending and adopted market-friendly policies and austerity measures supported by right-wing parties such as Movimiento CREO, 
Creando Oportunidades (CREO) and Partido Social Cristiano (PSC) (Labarthe and Saint-Upéry 2017; Wolff 2018; Navia and Umpierrez de Reguero 2021), which vaguely worked up to 2018, but went rapidly down in 2019 onwards. As the public expenditures continued to be higher than revenues and the public debt kept increasing (CEPAL 2018b; Paredes 2021), alongside the intensive social conflict in 2019 (Olivares and Medina 2020), Ecuador's economy remained under stress before and during the pandemic.

Figure 1. Real GDP growth (Ecuador, 2008-2020)

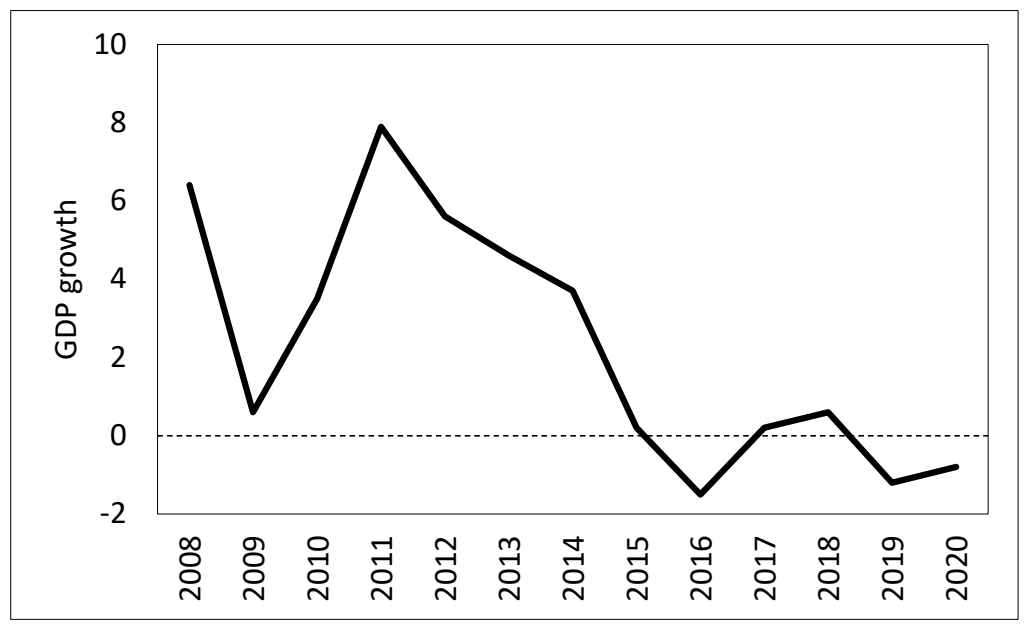

Source: Wolff (2018); BCE (2020)

The sanitary crisis pushed Moreno to declare a state of emergency and to take several important policy measures (see Section III). Unfortunately, these decisions negatively affected the economic and employment situation. Since non-essential business were closed or restricted by the public authorities from March to the end of 2020, and many other public and private companies reduced working hours, unemployment and sub-employment rates (calculated over the economically active population) increased (see Figure 2). From 2019 to 2020 , about $10 \%$ of full employees shifted to sub-employees. Moreover, the unemployment rate grew around 50\% between 2019 and the first months of 2021. 
Figure 2. Employment in Ecuador (December 2018-February 2021)

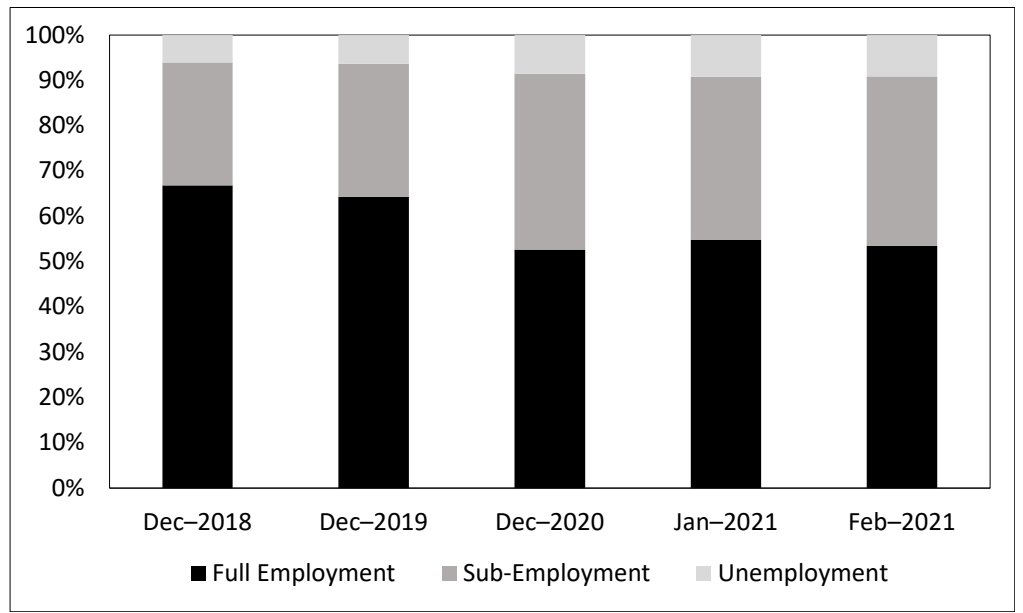

Source: INEC (2021)

According to official data, the extreme poverty rate increased severely in 2020 as compared to 2019 (more than 65\%) (see Figure 3). In 2020, 14.9\% of the population lived in extreme poverty. This number is comparable to 2009. The poverty rate at the end of 2020 also increased around 7\% as opposed to 2019 (from $25.0 \%$ to $32.4 \%$ ). Overall, this is the first year in almost one decade in surpassing a $40 \%$ threshold of poverty, reversing significantly what Ecuador reached over the last 15 years (CEPAL 2018a). Additionally, the Gini coefficient also augmented, meaning not only high rates of poverty, but also higher income inequality than previous years (INEC 2021).

Figure 3. Poverty and Extreme Poverty in Ecuador (2007-2020)

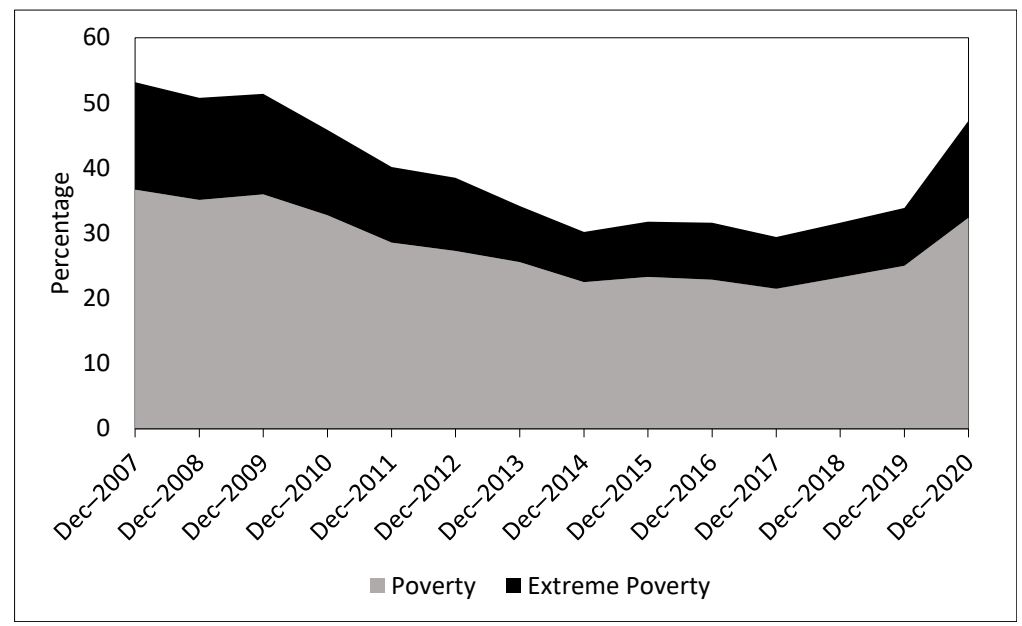

Source: Authors' own elaboration, based on Paredes (2021) 


\section{Social context}

Three key societal issues marked Ecuador over the 2020: gender-based violence, migration governance and prisoners' uprising. As other Latin American countries, because of the restrictive measures taken by the government to combat the sanitary crisis such as lockdowns (see Section III), gender-based violence increased in the country during the highest peaks of COVID-19 pandemic (AMMFE Ecuador 2021). Even before the sanitary crisis, this issue was growing in saliency. At the end of 2019, Ecuador received a visit from Dubravka Šimonović, the UN Special Rapporteur on violence against women. She issued her final report in May 2020 and urged to improve efforts to address gender-based violence as well as child and adolescent pregnancies with a unified legal framework (Human Rights Watch 2020). Domestically, social mobilizations before and during the sanitary crisis led by the Feminist and LGBTI+ movements exerted pressure on the central government for social policy responses regarding abortion due to violation and feminicides (El Comercio 2020a; El Comercio 2020c).

Gender-based violence was not the only societal issue to be exacerbated during the pandemic. In August 2019, the Ecuadorian government began the process of registering Venezuelans and issuing humanitarian visas to regulate their legal status in the country. As of August 2020, 362,862 Venezuelan, immigrants and refugees, lived in Ecuador. However, the COVID-19 pandemic precipitated the departure of many Venezuelans who returned to their country because they did not have access to food and employment and could not pay rent (Human Rights Watch 2020). Besides, there have been xenophobic acts against Venezuelans in the public sphere before and during the COVID-19 pandemic (Ramírez et al. 2019; González et al. 2021; Malo 2021). The previous deadline of March 2020 for Venezuelans already living and working in Ecuador to regularize their situation was extended until August due to the pandemic. At the end of this process, the government granted 38,246 humanitarian visas (Human Rights Watch 2020).

A third social conflict emerged in August 2020, when an uprising took place at the Littoral Penitentiary in Guayaquil. According to official reports, at least 11 prisoners died in the riots. Days later, in the same establishment, a key witness in a corruption case was also murdered, and two detainees died in a Cotopaxi prison (Human Rights Watch 2020). Accordingly, Moreno declared a state of emergency in all prisons and sent the military to cooperate in security operations. Regardless, in February 2021 and as a result of several riots in different prisons around the country, about 80 inmates died (Puente 2021).

\section{Political context}

After the October 2019 protests, data showed that more than $80 \%$ of the citizens assert that the president, Lenín Moreno, did not act or proceeded correctly in 
terms of political decisions to halt the chaos in capital's streets ${ }^{2}$ (IMASEN and Gavilanes, 2019). Similarly, around $80 \%$ of the respondents disapproved the political actions of the then Minister of Interior, María Paula Romo. About 70\% of the citizens disagreed on the performance of the judiciary, particularly the Office of the Attorney General. A similar outcome holds true to the National Assembly. Likewise, more than $50 \%$ of Ecuadorians seem to be unsatisfied with military and police personnel. Overall, public disaffection has largely affected Ecuadorian politics over the last year.

Since the departure of Rafael Correa from the presidency, the polarization between pro- and anti-Correa movements proved to be a useful frame to interpret and analyze domestic politics in Ecuador. At the end of Correa's last term in 2017, this polarization was understood as one of the greatest challenges that Moreno, his successor, would face (Wolff 2018). The promise of the 'government of dialogue' was precisely Moreno's response to this split (Rodríguez 2020). Indeed, this political identity was present prior to the general elections of February 2021 (see Table 1). Our public opinion survey demonstrates that hard-leaning pro- and anti-Correa voters seem to increase over time $(+7.23 \%$ and $+0.90 \%$, respectively), whereas indecisive voters otherwise.

At the end of these four years of Moreno's government, the political party that provided the electoral mass support, Alianza Patria Altiva I Soberana (APAIS) disappeared from the electoral board, bringing together a new scenario to Ecuadorian politics (see Section V). APAIS, which was founded by Correa and was the hegemonic party for about a decade (Mélendez and Moncattaga 2017), suffered an internal earthquake in 2017-a considerable part of party members and activists left the organization (Meléndez and Umpierrez de Reguero 2021). In the 2019 local and regional elections, the party Fuerza Compromiso Social (FCS), taken over by Correa in 2017, obtained part of APAIS' previous votes (Dandoy 2019).

Table 1. Intention to vote for a pro-Correa candidate in the next elections $(2019-2021)^{3}$

\begin{tabular}{lcccc}
\hline & \multicolumn{3}{c}{ Would you vote for a pro-Correa candidate in the next elections? } \\
\hline & \multicolumn{3}{c}{ President } & \multicolumn{2}{c}{ Assembly Member } \\
\hline & 2019 & 2021 & 2019 & 2021 \\
No, definitely & 37.98 & 41.04 & 39.70 & 41.27 \\
No, probably & 19.48 & 11.71 & 23.37 & 13.34 \\
Yes, probably & 22.85 & 20.87 & 23.15 & 22.11 \\
Yes, definitely & 19.70 & 26.38 & 13.78 & 23.27 \\
\hline
\end{tabular}

Source: Authors' own elaboration, based on Ríos and Umpierrez de Reguero (2021).

1,170 respondents from 16 to 70 years, nationwide (in both urban and rural areas). Surveys were done in 2019 through in-situ personal interviews (IMASEN 2019).

3 The 2019 survey, launched after the 2019 social mobilization, comprises 1,337 responses, while the 2021 survey, launched prior to the 2021 general elections, contains 1,289 responses. 
Since Moreno assumed the presidency in 2017, his government has implemented policies aimed at repairing what his cabinet has named 'the damage' caused to democratic institutions during the administration of Correa (2007-2017). Moreno's government institutional reforms have restructured and apparently restored the independence of key institutions such as the Judicial Council and the National Electoral Council (CNE); despite evidence that policy implementation challenges remain in each one of them, particularly during the COVID-19 pandemic.

With regard to citizen's perception of democracy, around 50\% of the Ecuadorians have declared that democracy is absolutely important from 2010 to 2020 (EVS/WVS 2020). Yet, there is a moderate preference variation recently (20172020), leaning to the extremes of the 10-point scale used by World Values Survey to assess whether democracy can be perceived as 'absolutely important' or 'not at all important'. In comparative perspective with the Andean region, Ecuador is slightly under the average with citizens who believe democracy is important, while it is over the mean concerning those who declared democracy is not important at all (EVS/WVS 2020).

Alongside the subjective importance of democracy -egalitarian, and participatory democracy indexes-, which measure the extent of whether formal rights and liberties are exercised by all social groups and if all citizens can actively participate in all electoral and non-electoral processes, seem to drop as compared to 2017-2018 (Coppedge et al. 2021). In fact, these figures are analogous to the levels observed during the first two presidential terms of Correa (20072013). However, liberal and electoral democracy indexes remain quite stable during the Moreno's administration (2017-2021). This means higher degrees of political and civil liberties as well as similar levels of participation and contestation, than the last Correa's presidential term (2013-2017), which was characterized by repetitive restrictions in media freedom (Montúfar 2016; Vera Rojas and Llanos-Escobar 2016) and labelled as competitive authoritarianism (Basabe-Serrano and Martínez 2014; Meléndez and Moncagatta 2017; Umpierrez de Reguero 2016). Ecuador is considered as an electoral democracy during the Moreno's government (2017-2021), which is a political regime with de facto fair and free multiparty contestation and a minimum degree of Dahl's institutional prerequisites for polyarchy as measured by V-Dem's Electoral Democracy Index, yet some minor interruptions to civil and political freedoms (Lührmann et al. 2018). 
Figure 4. Quality of democracy (2007-2020)

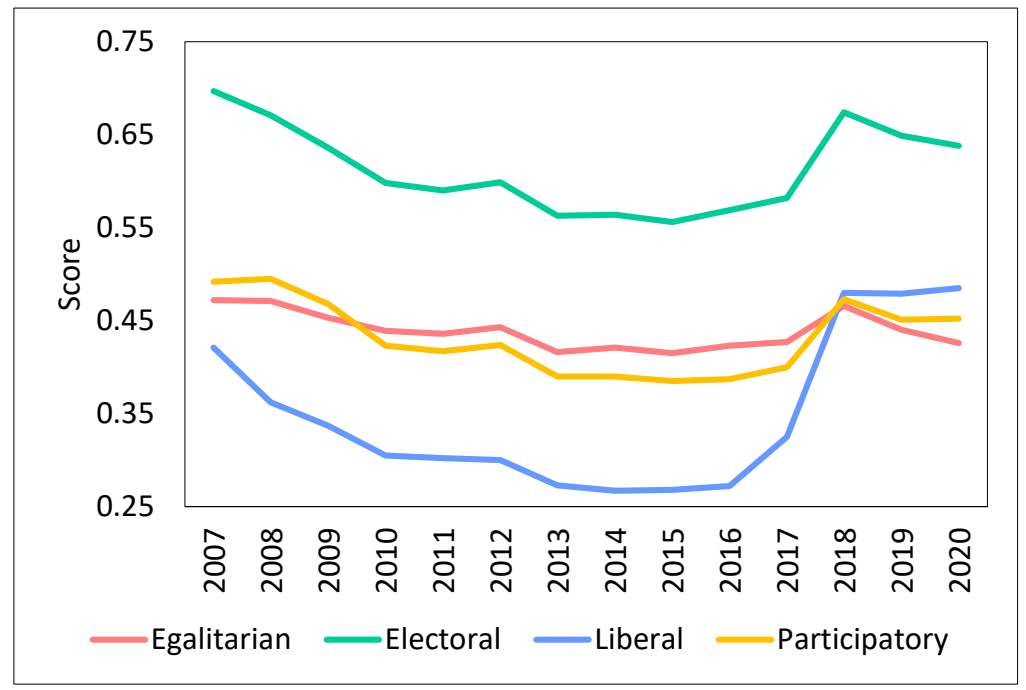

Source: Coppedge et al. (2021)

\section{COVID-19 IN ECUADOR}

As every country around the globe, the COVID-19 pandemic has strongly affected Ecuador in several ways during the 2020. Ecuador reported its first confirmed case in late February, and its first deaths in mid-March (Ministerio de Salud Pública 2021). From a local prevalence (between the provinces of Guayas and Los Ríos), the COVID-19 rapidly spread all over the national territory in about one month. The Moreno's government restricted the free mobilization from the second week of March, so that the COVID-19 would not escalate nationwide. Despite this measure, the first wave of the COVID-19, particularly in Guayaquil, left chaos, grief, and thousands of deaths, partly associated with the lack of healthcare access and shortage of medicines to treat COVID-19 patients in hospitals and other medical centers. Between March and April, alongside the overall dearth of COVID-19 tests, Ecuador was already one of the most affected cases in the region next to Brazil. This was not only because of the numbers of infected cases per inhabitant, but also due to the high death toll as well as the shocking images of deaths lying in several streets of Guayaquil (Zibell 2020).

Aligned with the state of emergency declared by Moreno in mid-March 2020, the following measures were implemented by the Emergency Operative Committee (COE) and executive agencies: preventive isolation (both domestic and international); strict daily curfew; closure of non-essential business; online work and classes (of all levels of education); economic aid and allocation of food supplies for low-income households; emergency scheme of taxation for individuals and companies; flexibility to reduce or limit labor benefits for pub- 
lic and private employees, and payment of foreign debt (Espinoza 2020). Ecuador was the first South American country in closing its national borders.

Regarding the domestic economy and citizens' well-being, this set of measures promptly generated public disaffection toward the central government and some local municipalities. It also stressed the difficulties to comply with the rules, and revealed a significant digital divide nationwide, which intensified the crisis (Espinoza 2020). The Moreno's administration suggested that if the foreign debt would be paid by the Ecuadorian government, along with a better fiscal income, the odds of obtaining a new loan from an international creditor such as the International Monetary Fund (IMF) would increase (España 2020). Yet, Ecuador's situation remained critical during the 2020, with not enough resources to combat the pandemic, particularly in rural areas and in the largest cities such as Guayaquil or Quito.

At first glance and in contrast to other countries in the region, the official numbers of COVID-19 cases in Ecuador do not seem too dramatic compared to what might be observed in practice (see Figure 5). As of late February 2021, the confirmed cases were about 300,000, and the death toll less than 16,000. Indeed, this meant a death share more than twice (5.53\%) higher than the global average (about 2.15\%) (Dong et al. 2020). Yet, given the shortage of COVID-19 tests, particularly RT-PRC, some policy makers as well as the overall citizens' perception indicate that the numbers may have been much higher (Espinoza 2020). In general, the informality and lack of reliable data created some distrust in the population (Palacio 2020: González-Bustamante 2021).

Figure 5. Cumulative deaths, confirmed, recovered cases of COVID-19 in Ecuador (Mar 2020-Feb 2021)

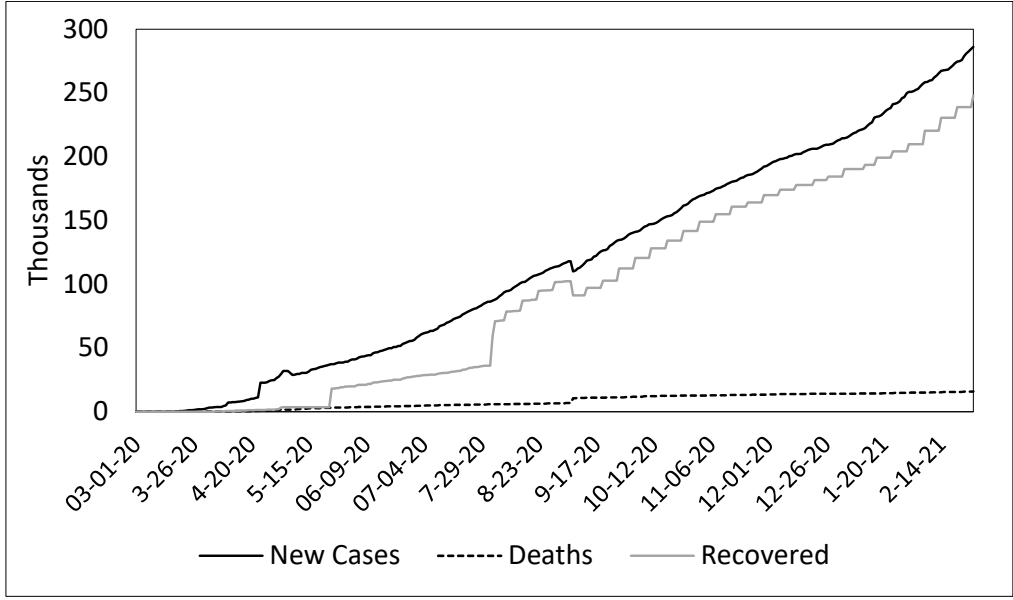

Source: Dong et al. (2020) 
The Ministry of Public Health has periodically disclosed COVID-19 statistics, disaggregating the number of confirmed cases and deaths per territorial jurisdictions. Based on these statistics, we observe that Guayaquil (province of Guayas) suffered the most in the first wave, whereas Quito (province of Pichincha) had two clear-cut peaks, one in July and another at the end of the 2020. Both cities have fluctuated in first places in terms of confirmed cases by RT-PRC. However, the most affected cantons and provinces in terms of deaths are to be found in Santa Elena and Manabí, considering their death rate of COVID-19 over the total number of confirmed cases (see Table 2).

Table 2. Deaths and confirmed cases of COVID-19 by RT-PRC in Ecuador (up to March 2021)

\begin{tabular}{|c|c|c|c|c|c|}
\hline Province & $\begin{array}{c}\text { Confirmed by } \\
\text { RT-PCR }\end{array}$ & $\begin{array}{l}\text { Deaths (of } \\
\text { confirmed by } \\
\text { RT-PCR) }\end{array}$ & $\begin{array}{c}\text { Deaths } \\
\text { (COVID-19 } \\
\text { associated) }\end{array}$ & $\begin{array}{c}\text { Total Death } \\
\text { by } \\
\text { COVID-19 }\end{array}$ & $\begin{array}{c}\text { Death share } \\
\text { (over confirmed } \\
\text { by RT-PRC) }\end{array}$ \\
\hline Azuay & 18,879 & 338 & 30 & 368 & 1.95 \\
\hline Bolivar & 4,980 & 85 & 19 & 104 & 2.09 \\
\hline Carchi & 6,117 & 210 & 3 & 213 & 3.48 \\
\hline Cañar & 4,472 & 117 & 8 & 125 & 2.80 \\
\hline Chimborazo & 5,920 & 409 & 129 & 538 & 9.09 \\
\hline Cotopaxi & 9,009 & 397 & 94 & 491 & 5.45 \\
\hline El Oro & 14,986 & 779 & 218 & 997 & 6.65 \\
\hline Esmeraldas & 7,020 & 302 & 60 & 362 & 5.16 \\
\hline Galapagos & 1,346 & 9 & 7 & 16 & 1.19 \\
\hline Guayas & 42,514 & 2,145 & 1,726 & 3,871 & 9.11 \\
\hline Imbabura & 9,608 & 285 & 20 & 305 & 3.17 \\
\hline Loja & 12,475 & 364 & 72 & 436 & 3.49 \\
\hline Los Ríos & 9,286 & 409 & 276 & 685 & 7.38 \\
\hline Manabí & 25,118 & 1,794 & 1,101 & 2,895 & 11.53 \\
\hline $\begin{array}{l}\text { Morona Santi- } \\
\text { ago }\end{array}$ & 4,654 & 48 & 1 & 49 & 1.05 \\
\hline Napo & 2,431 & 90 & 3 & 93 & 3.83 \\
\hline Orellana & 2,506 & 62 & 21 & 83 & 3.31 \\
\hline Pastaza & 2,740 & 73 & 18 & 91 & 3.32 \\
\hline Pichincha & 114,664 & 2,494 & 328 & 2,822 & 2.46 \\
\hline Santa Elena & 3,683 & 410 & 280 & 690 & 18.73 \\
\hline Santo Domingo & 9,241 & 524 & 124 & 648 & 7.01 \\
\hline Sucumbíos & 3,892 & 126 & 3 & 129 & 3.31 \\
\hline Tungurahua & 11,020 & 437 & 327 & 764 & 6.93 \\
\hline $\begin{array}{l}\text { Zamora Chin- } \\
\text { chipe }\end{array}$ & 2,194 & 70 & 2 & 72 & 3.28 \\
\hline Total & 328,755 & 11,977 & 4,870 & 16,847 & 5.12 \\
\hline
\end{tabular}

Source: Authors' own elaboration, based on the Ministerio de Salud Pública (2021).

In addition to the number of deaths, confirmed and recovered cases, the COVID-19 impacted every public and political domain. According to V-DEM 
(Edgell et al. 2020), Ecuador has somewhat imposed an abusive law enforcement between March to September 2020, as well as has restricted the media freedom from October to December 2020. Ecuador ranks in 68 and 102 positions out of 144 countries in terms of 'pandemic backsliding' and 'pandemic violations of democratic standards' indexes, respectively. Combined, these indexes provide an insightful picture on the emergency responses to the COVID-19 and their impact to the quality of democracy within the country (Edgell et al. 2020).

The National Assembly, along with other public institutions, applied a special procedure for remote working since March 2020. Each committee and the plenary enabled electronic voting for their legislative work. Sessions were broadcasted via social networking platforms such as YouTube and Facebook (see Inter-Pares Parliaments in Partnership 2021). At the initial stages of the pandemic, assembly members from all the political groups agreed on the importance of exercising oversight over the executive and ensuring transparency and access to relevant legislative information (IPU 2021). Accordingly, assembly members passed laws to regulate political and public life, and a set of rules to manage the sanitary crisis (see Section IV). First, they approved the Organic Law of Humanitarian Support to Combat the Health Crisis derived from COVID-19. Thereafter, assembly members promulgated several other laws to complement prior efforts as omnibus bills (Huertas-Hernández 2021).

Unlike other Latin American countries (e.g., Brazil and Colombia), the COVID-19 did not activate social mobilizations in Ecuador, except for one, which was in May 2020, lasted one day, and about 4,000 citizens took part (Carnegie Endowment for International Peace 2021). Trade unions and civic organizations were the main actors in a COVID-19 protest triggered by the announcement of the closure of few public (i.e., state-owned) companies, and reductions in public servants' salaries.

In February 2021, Ecuador was the third South American country to hold national elections during the pandemic. To reduce the contagion, traditional campaigns and rallies were banned (IDEA 2021). The CNE limited in-person electoral campaign events to be solely long walks and caravanning. Coupled with these measures, mobile ballot box voting was offered to citizens and foreign residents over 50 years of age and with a physical disability (National Council for Disability Equality 2021). In-person voters in Ecuador and outside (i.e., outof-country voting), were required by the $\mathrm{CNE}$ and health authorities to wear facemasks and maintain two-meters social distance, as well as use hand sanitizer before entering the polling station. The CNE also recommended voting in shifts for preventing crowds. Furthermore, informal commerce and street vendors, which has been a typical element around polling stations in Ecuador already for decades, were forbidden (OAS 2021). Despite the CNE providing personal protective equipment for polling station staff, the Organization of the American States (OAS)'s delegates, who observed the elections, reported bio-safety irregularities such as the lack of recommended ventilation in order to avoid the COVID-19 transmissions in some polling stations (OAS 2021). 
Immediately after the February 2021 elections, a Pulso Ciudadano's survey revealed that $96 \%$ of Ecuadorians were unsatisfied with the performance of Moreno toward the sanitary crisis (Informa Ecuador 2021). This survey also showed that $85 \%$ of the population found 'bad' or 'very bad' the central government's coordination through COE with municipalities. As of local governments, a wide majority of citizens residing in Quito perceived that their mayor, Jorge Yunda, did a '(really) good' job during the pandemic, while 79\% of Guayaquileans have a negative perception of Cynthia Viteri, Guayaquil's mayor.

\section{POLITICAL INSTITUTIONS DURING THE 2020}

\section{Executive}

After the 2017 elections, the vice-presidency in Ecuador proved to be an institutional source of conflict and instability: a new vice-president was elected or appointed almost every year. After the only elected vice-president, Jorge Glas ${ }^{4}$, Moreno provided a shortlist to the National Assembly to replace him. Assembly members selected María Alejandra Vicuña. She resigned due to corruption allegations after eleven months of being in office. Once again, from a presidency's shortlist, assembly members selected Otto Sonnenholzner as the third vice-president of Moreno's government. He remained in office from December 2018 to July 2020 (Asamblea Nacional 2020a).

In times of turmoil and high levels of conflict such as the COVID-19 pandemic, the vice-president role may be particularly relevant. Correspondingly, a third presidency's shortlist sent to the National Assembly nominated three appointees. Two of them were Moreno's closest collaborators: María Paula Romo and Juan Sebastián Roldán. This political strategy seemed to assure higher levels of legitimacy and loyalty toward the presidential office (Marsteintredet 2020). Searching for this profile, Sonnenholzner was replaced on July 17, 2020, by María Alejandra Muñoz

Muñoz was the third appointee, after the Minister of Interior, Romo, and the Secretary of the Cabinet, Roldán. Her nomination was preferred among Assembly Members over the two other nominees, particularly because of the corruption scandal involving Romo in the misappropriation case in exchange for votes in the National Assembly (Asamblea Nacional 2020b) ${ }^{6}$. Muñoz obtained 75 affirmative votes, 22 negative and 38 abstentions. With the legislative dic-

Jorge Glas was removed from office by court ruling.

Previously, Muñoz was the General Director of the National Custom Services (SENAE), and the Sub-Secretary of the Presidential Agenda.

6 These allegations were part of the case of former assemblyman Daniel Mendoza involved in the corruption episode of the Pedernales hospital (Manabí province). 
tum, Muñoz was the fourth and last vice-president, who has passed through Moreno's government (see Table A1 in Annex).

In line with the corruption scandals, alongside the crisis generated from the COVID-19 pandemic, Moreno renewed several members of his ministerial cabinet to allegedly face the last stretch of his term in government (GK 2020), from March to July 2020. The cabinet continued to change at the end of 2020, and even at the beginning of 2021. For instance, Juan Fernando Velasco acted as Minister of Culture and Heritage until September 2020 to become a presidential candidate. Thereafter, Angélica Arias replaced him as interim minister for four months and in January 2021, Julio Bueno Arévalo was finally designated as minister. Likewise, the Ministry of Economy and Finance was one of the institutions with the largest media attention in Moreno's government administration. Richard Martinez resigned in October 2020 and Mauricio Pozo was the new appointed minister.

In the Minister of Public Health, Catalina Andramuño presented her resignation in March 2020 coinciding with the first wave of COVID-19 pandemic. She enclosed a public letter justifying her resignation due to the lack of necessary funds to manage the pandemic despite having requested them to the government (Asamblea Nacional 2020d). With her resignation she also avoided the continuation of an impeachment process initiated against her in the National Assembly. Juan Carlos Zeballos assumed this ministry for one year (see Table A2 in Annex).

Overall, the government institutional capacity to interact with other sectors and at different levels (Rahman 2016) during the COVID-19 pandemic was showing drawbacks. Moreno's administration demonstrated a lack of public problem-solving capacity, especially concerning the decisions taken to face the sanitary crisis. In his four years in office, Moreno did not substitute the Executive Legal Secretary, Johana Pesántez and the Secretary of Sports, Andrea Sotomayor. They were in Moreno's cabinet since he assumed power on May 24, 2017 (Vélez 2021).

\section{The legislature}

In 2020, virtual plenary sessions were activated as the main arena to debate and legislate due to the COVID-19 pandemic. For almost ten consecutive months, assembly members discussed bills through an online platform. The first session of this kind, with 117 (85.4\% of the) assembly members present, was installed on March 24, 2020, precisely to discuss a draft resolution concerning the sanitary crisis (see Section III).

During the pandemic, executive-legislative coordination was essential to enact the state of emergency and related omnibus bills (Huertas-Hernández 2021). Both branches made further efforts and launched a series of legislative initiatives to promote using mobile location and personal data. In September 
2019, President Moreno-because of a massive disclosure of citizens' personal data - sent a bill on data protection to the National Assembly. These initiatives took relevance given its possible usefulness to monitor compliance with quarantine measures adopted in relation to the COVID-19. Unfortunately, these initiatives, which included satellite monitoring of those suspected of having the COVID-19, have been neither enacted nor implemented.

Besides those urgent health-related bills, the National Assembly processed 23 laws in 2020, but only 19 of them were published in the Official Registry (see Table A2; Figure 6). From the other four, two await from the Executive pronouncement, only one was partially vetoed, and one was totally objected. Among the laws approved and published in the Official Registry, assembly members addressed issues of entrepreneurship, innovation, strengthening the Comptroller's Office functions, electoral reform, food policy and fishing, agriculture, environmental and mining issues, combating drug micro-trafficking, social security, labor stability, simplification of bureaucratic procedures, human mobility, as well as fight against corruption.

On August 25, 2020, the National Assembly approved a new Health Code. This law bans delaying healthcare attention for any reason, including conscientious objection by healthcare workers. It also reiterated the obligation of healthcare workers and professionals to respect medical confidentiality, including in cases of obstetric emergencies. Feminist groups sympathized with this new legal framework, since the National Assembly rejected in 2019 a proposal to decriminalize abortion in cases of rape and serious fetal malformation. However, on September 25, 2020, President Moreno announced his total veto of the code.

Figure 6. Approved Laws and Reforms in Ecuador (from January to December 2020)

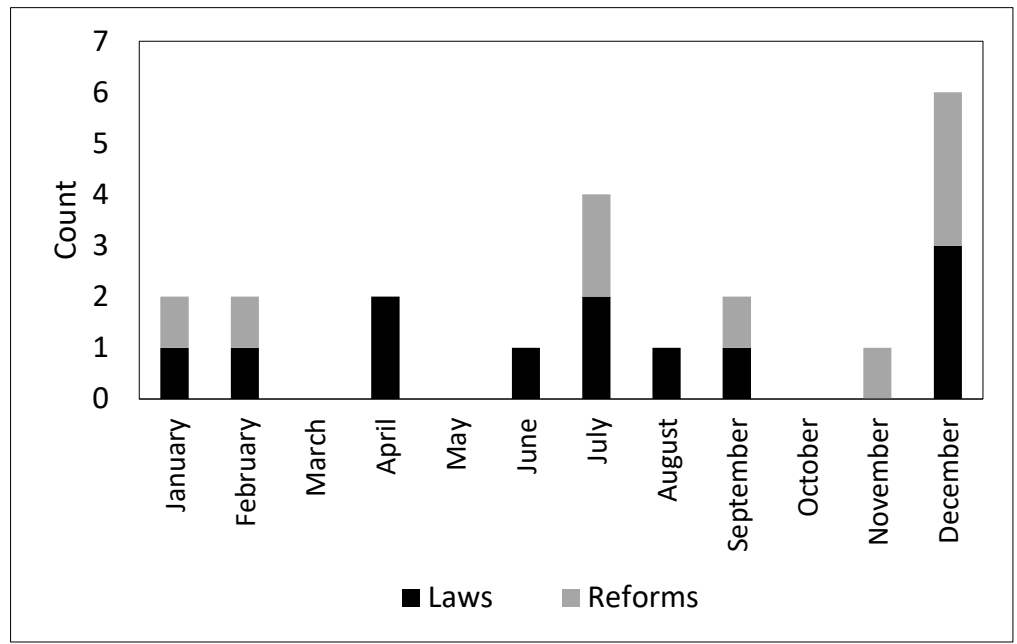

Source: Authors' elaboration based on Asamblea Nacional (2021). See Tables A3 and A4. 
Corruption scandals in 2020 reached some assembly members, leading to the resignation of two of them: Daniel Mendoza (APAIS-Unidad Primero) and Eliseo Azuero (Independent), involved in a network of corruption when constructing a hospital in Pedernales (province of Manabí). Viviana Bonilla (APAIS) also lost her legislative seat due to aggravated passive bribery during latest Correa's presidential term and was sentenced to eight-years in prison (Sobornos Case, 2012-2016). Meanwhile, the processing of an investigation request to Karina Arteaga (APAIS), associated with the National Assembly's tithes, and processing of the Health Commission's report, which investigated the cases of delivery of disability identification cards, are pending.

Besides its legislative function, the National Assembly also oversights government's actions. The National Assembly processed three political trials from January to November 2020. Based on voted and approved reports from the Commission of Political Oversight and Control, the impeachment processes concerned the former Minister of Culture and Heritage, Raúl Pérez Torres, the president of the Council for Citizen Participation and Social Control (CPCCS), Christian Cruz, and the former Minister of Interior, María Paula Romo.

The first impeachment took place at the beginning of the 2020. Former minister Raúl Pérez Torres was accused given the issuance of the Regulations to the Organic Law of Culture. This regulation established the formula to allocate funds for the Ecuadorian Culture Organization and its 24 provincial branches. It caused serious economic losses for smaller provinces (Asamblea Nacional 2020d). In his defense, the former Minister of Culture stressed that his actions were not political but professional and that he had questioned the Law of Culture and the formula for resources' allocation executed through the Ministry of Finance (Asamblea Nacional 2020d). Despite these allegations, there were not the required votes for his censorship.

In October 2020, a second process of impeachment was initiated in the National Assembly Plenary. With 124 affirmative votes, the Assembly censured Christian Cruz Larrea from the Council for Citizen Participation and Social Control (CPCCS). He was challenged for non-compliance of his functions and by assuming other functions when issuing regulations that were out of his institutional competence. He was also accused of irregularly acquiring disability identification card (Asamblea Nacional 2020d).

A month later, in November 2020, with the vote of 104 assembly members, the Plenary of the National Assembly censured the Minister of Government, María Paula Romo. The main reason for her removal was considering that she was politically responsible for the actions of the National Police and the operation to quell the demonstrations occurred in October 2019, which led to acts of violence (Asamblea Nacional 2020c). Romo was accused of using expired tear gas canisters to disperse protesters and attack humanitarian reception centers where indigenous people were sheltered (Asamblea Nacional 2020c). The excessive use of force in the October 2019 demonstrations left many citizens dead, 
hundreds injured, and people persecuted for the mere fact of having protested against an unconsented measure adopted by the Government. The impeachment process took place virtually. Romo was in the Carondelet Palace - headquarters of the Executive (Asamblea Nacional 2020c).

\section{The Judiciary}

Like other public institutions, the judicial branch demonstrated inter- and intra-coordination problems to mitigate the sanitary crisis. As a result of the COVID-19 pandemic, three major events are worth mentioning. First, the dispute over judicial budget with the executive. Second, the disagreement with the Constitutional Court for guaranteeing access to justice. Lastly, the dispute on the selection of new judges for the National Justice Court with the CPCCS.

Between 2019 and 2020, budget cuts to the judicial branch were around USD 19.5 million (El Comercio 2020b). To this amount, another USD 2 million in contracts for investment projects on violence against women and families were promised by the Ministry of Economy, yet thereafter failed to be allocated. Without the financial resources coupled with the health crisis, it became difficult to comply with institutional activities and interventions initially programmed to foster an efficient justice service.

In 2020, the labor relations with 26 justice servers were ended. This factor considerably reduced justice efficiency. Indeed, the deficit of judges and judicial personnel -that were not replaced-along with the activity's reduction following the state of emergency guidelines, daunted processing judicial causes and directly affected users. For example, budget restriction had a negative impact on the adjustment's implementation in the specialized Judicial Units on Violence against Women, around the country.

In May 2020, 804,533 court cases were pending, in all instances. Between 2019 and June 2020,734,490 hearings were convened, of which 501,326 were held (less than 70\%). During the 2020, an average of 14,444 proceedings per month of this type were carried out nationwide (Ortiz 2020b).

As a result of the budget cuts between 2019 and its contraction in the 2020, the judges halted the dispatch of cases. The Judicial Council informed that in the Family Court up to the end of June 2020, there were 252,679 pending lawsuits to be resolved in the country (Ortiz 2020b). These were trials for alimony, visitation regimes, adoptions, divorces, paternity claims, among others.

Some of these trials began even before the pandemic. Between March 17 and June 5, 2020, the dispatch of this type of processes was suspended because the Judiciary closed Family Courts. Allegedly, this decision stems from a sanitary measure to prevent the massive transmission of the COVID-19. In sum, the 
dispatch of cases worsened with the pandemic and the budget. For 2020, 26 officials were dismissed (Ortiz 2020b).

In fact, right after Moreno issued the state of emergency in response to the COVID-19 pandemic, the Judiciary Council closed most of its judicial units except those administering issues in criminal justice, domestic violence, trafficking, and juvenile delinquency (Vivanco 2020). On April 28, 2020, the institutional counter-reaction came from the Constitutional Court. The Court ordered the Judicial Council to adopt clear and timely measures to guarantee Ecuadorians' access to justice. Court members justified their argument based on international affairs institutional setting and human rights legal regulations (Vivanco 2020), in which guaranteeing access to justice in times of emergency has been framed as mandatory.

The five vocals of the Judiciary stated that any other institutional injunction violates the principles of independence and autonomy. According to their perception, the judicial branch has the constitutional legitimacy and power to issue resolutions to safeguard the continuity of its public services during a state of emergency, thus any other public institution has the right to oversight its role (Vivanco 2020).

The Public Contest of Opposition and Merits for the selection and appointment of the judges of the National Court of Justice, in turn, aimed to renew a third part of the magistrates (about 16 vacancies). In July 2020, the Judiciary Council publicly started the selection process. When the public contest began, there were irregularities within the judicial technological computer system (Rosero 2020a). The CPCCS intervened as overseer of the citizenry and declared the need to annul the public selection of the new judges for the National Court of Justice. One of their main reason was that the public contest had not been legally and timely notified to all Ecuadorians (Ortiz 2020a). Reiteratively, the judicial responded rejecting that CPCCS's allegation as well as any unfounded assertion regarding the lack of legal transparency of the process (Ortiz 2020a). For Judiciary members, suspending the public contest or declaring it null would have constituted a transgression on the rights of most applicants (Rosero 2020b).

\section{ELECTIONS}

\section{Changes in the electoral and party system prior to the 2021 elections}

The first important feature of the 2021 electoral process concerns the reforms of the electoral system. The project of reform was initiated in August 2017 by the CNE and was subject to a first debate in the National Assembly in October 2017. The objective of this reform was to improve the electoral process from a juridical 
and technical perspective to enhance the voting rights of Ecuadorian citizens. After a political break of almost two years, a second debate was held in the National Assembly, and the legislative project was voted with a quasi-unanimity (113 votes in favour, one against and five abstentions) on December 3, 2019. This legislative project aimed at improving the democratic character of the electoral process and its transparency, as well as controlling electoral expenditures. After a partial objection from the executive, the law was officially published on February 3,2020 , almost exactly one year before the 2021 elections.

Among the numerous changes in the electoral legislation, a key element relates to the modification of the voting system employed in all plurinominal elections. Ecuador was one of the few countries worldwide that used panachage (i.e., voters can vote for several candidates on different lists). Since this reform, Ecuador returned to a closed-list system (see Mejía Acosta 2002). Additionally, the seat allocation method has also been revised, eliminating $\mathrm{d}^{\prime}$ Hondt and only using Webster for plurinominal elections. Among the other relevant elements that have been affected by the electoral reform, one might think of the organisation of presidential debates, the management of voters' registration, the funding of electoral campaigns, and a better gender balance at the candidate level.

Compared to the 2017 elections, the party system also suffered several changes. The most relevant one concerns the pro-Correa faction that seceded from APAIS in 2017-2018. After two attempts to create their new party, alongside an attempt to take over one existing party, this faction managed to fuse two parties, which were previously approved by the CNE: FCS in December 2018 and Centro Democrático (CD) in July 2020. Both parties were merged into an electoral alliance Unión por la Esperanza (UNES) for the 2021 national and Andean elections. Two other alliances were created at this occasion: one gathering CREO and PSC mostly for the presidential elections, and one merging the Partido Socialista Ecuatoriano (PSE) and Concertación in most districts. Among the parties that participated in the 2017 legislative elections (national seats), the only absent was Adelante Ecuatoriano Adelante that was dissolved by the CNE in June 2020. His leader Álvaro Noboa decided to move to another party (Justicia Social) to participate in the presidential elections (see below).

\section{Candidate and party registration issues}

As in previous elections, the electoral regulation, and its implementation by the CNE had a significant impact on the course of the electoral campaign. Political parties must be officially registered by the CNE and respect certain administrative and political rules, such as the organization of primaries. As a result, several political parties were not allowed to participate in the 2021 elections. The most striking example was the case of the party Justicia Social that could not partake in the presidential and Andean elections. This decision potentially had an important effect on the electoral process as Álvaro Noboa - the main 
candidate of Justicia Social - could not stand as a presidential candidate. Several opinion polls indicated that his candidature could have had a significant impact on the first-round of the presidential election.

Another dramatic consequence of the CNE's decision stemming from not authorizing Justicia Social to participate in the Andean elections resulted in almost endless legal debate between the $\mathrm{CNE}$ and the Contentious Electoral Tribunal (TCE). The final decision of the TCE regarding the non-participation of Justicia Social in these elections took place on January 31, 2021, no less than 8 days prior to election day. The printing of the voting ballots - that started on that same day - was fast enough to provide enough paper ballots for the voting population but it become soon impossible to send them on time to the Ecuadorian consulates abroad. As a result, most Ecuadorian voters living abroad could not vote for these elections. 113,544 voters that participated in presidential and legislative could not vote for Andean elections. However, our simulations indicate that these disadvantaged voters would not have changed the actual seat allocation, given the importance of the gap between the second seat of UNES and the potential first seat of CREO.

Another electoral regulation was discussed at length during the campaign and had a significant impact on the candidates allowed to compete in the presidential election. In order to be officially accepted as candidates for the presidency and vice-presidency, potential candidates need to be physically present in the CNE venues in Quito. However, this regulation prevented two important political figures to formally accept their candidacy and therefore to participate in the elections. The former president Abdalá Bucaram (Fuerza Ecuador) was at the time under house arrest for investigations of organized crime such as the irregular sale of medical supplies and illegal possession of a firearm. Similarly, Rafael Correa (UNES), that was at the time living in Belgium, decided not to come physically to Ecuador to accept his candidacy as vice-president. The former president was sentenced to eight years in prison for bribery in the socalled Sobornos case and would most likely be arrested upon his arrival on the Ecuadorian soil.

These political figures - Noboa, Bucaram and Correa - joined the group of major absentees, i.e., prominent political leaders that decided not to participate in the 2021 presidential elections. Among this group, we find the incumbent Lenín Moreno (APAIS) that decided not to run for a second mandate, the former mayor of Guayaquil and historic leader of the PSC, Jaime Nebot, as well as Moreno's former vice-president Otto Sonnenholzner (independent). Given the absence of these prominent figures that would have potentially attracted significant vote shares, several candidates - sometimes from minor parties decided to participate in the presidential elections. No less than 16 candidates were accepted by the CNE for the presidential elections, including only one woman, Ximena Peña. There were 15 parties competing for 5 seats in the Andean election, 17 parties for the national seats in the legislative election, and an even larger number of parties for the provincial seats in the legislative election. 


\section{Election results}

The so-called 'general elections' took place on February 7, $2021^{7}$ and comprised four different electoral processes: the Andean parliamentary elections, the firstround presidential election and the two separate votes for the National Assembly (that is divided into 'national seats' and 'provincial seats'). A five-questions popular consultation on mining was organized simultaneously in the canton of Cuenca.

Given the pandemic, one could have forecasted a significant drop of turnout figures in the February elections, especially since voting is not compulsory for the voters aged 65 or above. Yet, turnout almost reached $81 \%$ for the presidential and legislative elections. This constitutes a small decrease compared to the previous elections $(81.63 \%)$ that also concerned a popular consultation. Turnout was slightly higher for Andean elections (82.25\%) given that a considerable share of non-resident Ecuadorians - that tend to participate less in elections and therefore lead to a drop of turnout figures - could not vote in Andean elections.

An important share of spoiled ballots (i.e., blank and null votes) is a traditional characteristic of electoral processes in Ecuador, mostly explained by the fact that voting is compulsory for a large share of the voting population. In the 2021 presidential elections, spoiled ballots accounted for $12.65 \%$ of the votes, which is a significant increase compared to the previous presidential elections $(9.77 \%)$. The share of spoiled ballot was even higher for the Andean elections $(25.22 \%)$ and the national elections (26.4\% for the national seats), also an important increase compared to previous elections.

The presidential elections delivered surprising results, particularly because opinion polls could not predict the vote shares for some of the main candidates (see Table 3). Andrés Arauz (UNES) accounted for $32.72 \%$ of the votes, followed by Guillermo Lasso (CREO-PSC) with $19.74 \%$ which is the weakest performance of this candidate compared to his two previous experiences. Both candidates were announced neck-to-neck up to some weeks before the elections, but the difference in the voting booths reached almost $13 \%$. Similarly, the indigenous candidate, Yaku Pérez (from Pachakutik) performed particularly well and obtained, with $19.39 \%$ of the vote shares, the second largest performance of his party in presidential elections. The most unexpected result comes from Xavier Hervas (from Izquierda Democrática [ID]) that reached $15.68 \%$, the best performance for this party since 1998. The candidate ran his campaign mostly on social media and appealed to younger voters. Apart from Pedro Freile, all the other candidates are below $2 \%$ of the vote shares. 
Table 3. 2021 first-round presidential election results

\begin{tabular}{lll}
\hline Party/Coalition & Presidential Candidate & Votes (\%) \\
\hline UNES & Andrés Arauz Galarza & $3,033,791(32.72)$ \\
CREO-PSC & Guillermo Lasso Mendoza & $1,830,172(19.74)$ \\
Pachakutik & Yaku Pérez & $1,798,057(19.39)$ \\
ID & Xavier Hervas & $1,453,915(15.68)$ \\
Amigo & Pedro José Freile & $192,763(2.08)$ \\
Avanza & Isidro Romero Carbo & $172,714(1.86)$ \\
Partido Sociedad Patriótica (PSP) & Lucio Gutiérrez & $164,800(1.78)$ \\
Ecuatoriano Unido & Gerson Almeida & $160,572(1.73)$ \\
APAIS & Ximena Peña Pacheco & $143,160(1.54)$ \\
Sociedad Unida Más Acción (SUMA) & Guillermo Celi & $84,640(0.91)$ \\
Movimiento Construye & Juan Fernando Velasco Torres & $76,349(0.82)$ \\
Alianza Honestidad & Cesar Montúfar & $57,620(0.62)$ \\
Democracia Sí & Gustavo Larrea Cabrera & $36,903(0.40)$ \\
Fuerza EC & Carlos Sagnay de la Bastida & $26,524(0.29)$ \\
Podemos & Paul Ernesto Carrasco & $19,809(0.21)$ \\
Union Ecuatoriana & Giovanny Andrade Salvador & $20,245(0.22)$ \\
\hline
\end{tabular}

Source: http://cne.gob.ec/es/procesos-electorales/elecciones-generales-2020?layout=edit\&id=5677.

The electoral results were challenged by Pérez. After the elections, the candidate for Pachakutik claimed that the presidential elections were rigged and that his vote share should allow him to participate in the ballotage, facing the UNES candidate. His legal action was supported by Pachakutik and several actions such as pacific demonstrations outside the CNE headquarter. Social mobilizations across the country and road blockades were organized by his supporters. On February 26, 2021, protests outside CNE headquarters created some tensions with the police. Still, the post-elections remained peaceful as compared to the 2017 elections. After that his legal case was extinct, Pérez called his supporters to spoil their ballots by emitting a null vote in the second-round of the presidential election.

The CNE ultimately announced the first-round presidential election's official results on February 21, 2021 (i.e., exactly two weeks after the elections). Given that none of the candidates reached $50 \%$ or $40 \%$ of the vote shares with a difference of at least $10 \%$ difference compared to the second highest preference, a ballotage is to take place on April 11, 2021. This second-round presidential elections will oppose two all-male tickets.

The effects of the introduction of the closed list for legislative elections are unknown, partly because the official election results for both national and provincial seats are not yet known at the time of closing this article (April 25, 2021). In addition, an analysis of party vote shares would rely on many potentially invalid assumptions regarding individual voting behaviour. Given the changes in the electoral system, it is also not possible to compare the legislative election results with the 2017 elections in terms of votes. Yet, the legislative election re- 
sults confirm that the National Assembly will be divided into five main political parties (see Table 4). Since none of these parties gathers an absolute majority of the seats, the future president will have to create parliamentary coalitions to pass legislation. ${ }^{8}$ The new assembly will also count $37.96 \%$ female legislators, which is not an improvement compared to 2013 and even a slight decrease compared to 2017 (39.42\%). In the Andean parliament, conversely, three of the five parliamentarians are female.

Three parties can be considered as the winners of the legislative elections: UNES (+49 seats), Pachakutik (+23 seats) and ID (+14 seats). APAIS (-74 seats) and CREO (-20 seats) lost a considerable number of seats, whereas PSC slightly strengthens its position. Finally, the election results for both the presidential and legislative elections also confirmed the importance of a geographic cleavage in Ecuadorian politics. UNES gathered its best results in the coastal provinces, while Pachakutik dominated the indigenous areas in the highland and Amazonian provinces. CREO and ID obtained significant vote shares in urbanized areas.

Table 4. 2021 legislative election results

\begin{tabular}{lccc}
\hline Party/Coalition & $\begin{array}{c}\text { Votes for national } \\
\text { seats }(\%)\end{array}$ & $\begin{array}{c}\text { Seats (national and } \\
\text { provincial) }\end{array}$ & Difference 2017-2021 \\
\hline UNES & $2,584,595(32.21)$ & 49 & +49 \\
Pachakutik & $1,348,679(16.81)$ & 27 & +23 \\
ID & $961,513(11.98)$ & 18 & +14 \\
PSC & $780,541(9.73)$ & 18 & +3 \\
CREO & $774,238(9.65)$ & 12 & -20 \\
Alianza Honestidad & $301,369(3.76)$ & 2 & +2 \\
APAIS & $222,092(2.77)$ & 0 & -74 \\
Ecuatoriano Unido & $166,888(2.08)$ & 2 & +2 \\
Avanza & $154,529(1.93)$ & 2 & +0 \\
PSP & $145,398(1.81)$ & 1 & -1 \\
Unidad Popular & $139,969(1.74)$ & 0 & 0 \\
SUMA & $135,038(1.68)$ & 0 & -2 \\
Democracia Sí & $84,209(1.05)$ & 1 & +1 \\
Fuerza EC & $70,854(0.88)$ & 0 & -1 \\
Union Ecuatoriana & $59,080(0.74)$ & 1 & +1 \\
Movimiento Construye & $57,711(0.72)$ & 1 & +1 \\
Podemos & $37,438(0.47)$ & 0 & 0 \\
Provincial parties & - & 3 & 0 \\
Total & $8,024,141(100)$ & 137 & - \\
\hline
\end{tabular}

Source: http://cne.gob.ec/es/procesos-electorales/elecciones-generales-2020?layout=edit\&id=5677. 


\section{A new Ecuadorian party system?}

The 2021 elections confirmed the radical change of the party system, a trend that was initiated in the 2017 and 2019 elections. Ecuador witnessed a system dominated by one single party for the period 2006-2017, but the recent elections predict a return to a multi-party system such as the one observed for the period 1979-2006 (Mejía Acosta 2002; Pachano 2010). Indeed, the 2021 elections proved to be disastrous for APAIS as its presidential candidate obtained a poor $1.54 \%$ of the vote shares, and the party did not manage to win any seat in the National Assembly. The same situation is observed concerning SUMA and Fuerza EC. The survival of other parties is also at stake in a near future as no less than 12 parties did not reach the threshold of $4 \%$ of the vote shares at the national level. They may be dissolved by the CNE if they do not perform better in future electoral processes.

On the contrary, these elections indicated that the Ecuadorian party system is now composed of one large party and four medium size parties. Other parties did not manage to obtain more than two seats in the National Assembly. Correa's political movement remains an important political force in the party system. Competing under a different name (UNES), the party obtained more than one third of the legislative seats, becoming the largest party at the National Assembly. It is opposed to four medium size parties - Pachakutik, ID, PSC and CREO - which all ran an anti-Correa campaign. Apart from Lasso's party that is more recent, they are historical parties that were created in the $20^{\text {th }}$ century. The local and regional elections of 2023 will be the occasion to confirm whether the Ecuadorian system returned to pre-2006 situation characterized by a multi-party feature and dominated by a few established parties.

\section{CONCLUSION}

The COVID-19 was one of the main challenges that Lenín Moreno faced over his presidency. In this article, we examined a multidimensional context as well as the main measures and impacts of the COVID-19 on Ecuadorian politics. Over the last year, the sanitary crisis has influenced every domain of public and political life in Ecuador. While the quality of democracy slightly dropped, the approval of Moreno, as well as several socioeconomic indicators, got severely affected. Beyond these impacts, Ecuador has suffered one of the most tragic first wave of COVID-19, in terms of death toll and media coverage, at the beginning of the pandemic as opposed to other South American countries. As of the beginning of 2021, the solution to overcome this crisis is yet unclear, considering how public authorities have managed it, and the citizenry has complied with the measures.

The institutional setting under Moreno's administration has demonstrated a lack of responsiveness. Although Ecuador has apparently recovered the independence of key institutions (e.g., Judiciary), Moreno's cabinet have been con- 
tinuously changed from February 2020 to February 2021, and public disaffection has been latent, particularly since a wide majority of the society declared that this government has not been efficient to combat the COVID-19 pandemic. In this context, Ecuadorian institutions deteriorated their performance and legitimacy during the 2020 .

Even if there have been no elections taking place in 2020 as compared to the last three years, the electoral theme remained high on the public agenda. An important electoral reform took place in February 2020, while the remainder of the year was dedicated to issues related to candidate and party registration. The results of the Andean and national elections of February 2021 confirmed the collapse of APAIS, the party that dominated Ecuadorian politics since 2006. In its place, the National Assembly witnesses the return of a multi-party system where no party obtained an absolute majority of the seats. Even if the presidential ballotage will oppose the candidates from UNES and CREO, Pachakutik and ID proved to be the winners of these elections and will undoubtedly be the cornerstone of the next president's attempt to gather a legislative majority.

\section{REFERENCES}

Altmann, Philipp. 2020. "Eleven Days in October 2019 - the Indigenous Movement in the Recent Mobilizations in Ecuador." International Journal of Sociology 50(3): 220-226.

AMMFE. 2021. "Ecuador cerró el año 2020 con 118 femicidios, sigue la tendencia de un feminicidio cada 72 horas". Available at: http://www.fundacionaldea.org/noticias-aldea/ltkb7e8a23fmcjg9ealt9ja59t8ygp

Asamblea Nacional, 2020a, July 10. "Asamblea Nacional Acepta renuncia de Otto Sonnenholzner como vicepresidente de la República". Retrieved on July, 6, 2021 from: https:/ / www.asambleanacional.gob.ec/es/noticia /67710-asamblea-nacional-acepta-renuncia-de-otto-sonnenholzner

Asamblea Nacional. 2020b, July 17. "Asamblea Nacional designa a María Alejandra Muñoz como vicepresidenta de la República". Retrieved on July, 6, 2021 from: https: / www. asambleanacional.gob.ec/es/noticia/67826-asamblea-nacional-designa-maria-alejandra-munoz-como

Asamblea Nacional. 2020c, November 5 "Fiscalización recomienda al Pleno proceder al Juicio político contra la ministra de gobierno". Retrieved on July, 6, 2021 from: https:// www.asambleanacional.gob.ec/es/noticia/69445-fiscalizacion-recomienda-al-pleno-proceder-al-juicio

Asamblea Nacional. 2020d, December 23. "La Asamblea procesó tres juicios políticos entre enero y noviembre de 2020". Retrieved on July, 6, 2021 from: https://www. asambleanacional.gob.ec/es/noticia/70074-la-asamblea-proceso-tres-juicios-politicos-entre-enero-y

Asamblea Nacional. 2021. "Consultation of proposals and bills." Retrieved on July, 6, 2021 from: https:/ / www.asambleanacional.gob.ec/es

Basabe-Serrano, Santiago and Julián Martínez. 2014. “Ecuador: cada vez menos democracia, cada vez más autoritarismo... con Elecciones". Revista de Ciencia Política 34(1): 145-170

BCE (Banco Central del Ecuador). 2020. Índice de Actividad Económica Coyuntural. Retrieved on July, 6, 2021 from: https://www.bce.fin.ec/index.php/component/k2/ item/313-indice-de-actividad-econ\%C3\%B3mica-coyuntural-ideac 
Borja, Maria Sol. 2020, July 7. "El retiro calculado de Otto Sonenholzner". GK. Retrieved on June 7, 2021 from: https://gk.city/2020/07/07/otto-sonnenholzner-deja-vicepresidencia/

Borja, Maria Sol, 2021, November 5. "La Vicepresidenta que quiere visitar al papa". GK. Retrieved on June 7, 2021 from https://gk.city/2020/11/05/viaje-vicepresidenta-vaticano/

Carnegie Endowment for International Peace. 2021. "Global Protest Tracker". Retrieved on June 7, 2021 from: https:/ / carnegieendowment.org/

CEPAL (Comisión Económica para América Latina y el Caribe). 2018a. Panorama Social de América Latina 2017. Santiago: Naciones Unidas.

CEPAL. 2018b. Panorama Fiscal de América Latina y el Caribe: Los desafíos de las políticas públicas en el marco de la Agenda 2030. Santiago: Naciones Unidas.

Coppedge, Michael, John Gerring, Carl Henrik Knutsen, Staffan I Lindberg, Jan Teorell, Alizada Nazifa, David Altman et al. 2021. "V-Dem [Country-Year/Country-Date] Dataset v11.1" Varieties of Democracy Project. Available at: https://doi.org/10.23696/ vdemds21

Dandoy, Régis. 2019. "Party strategies and performances in the 2019 provincial elections in Ecuador". Democracias 7(1): 133-153.

Dong, Ensheng, Hongru Du and Lauren Gardner. 2020. An interactive web-based dashboard to track COVID-19 in real time. Lancet Infectious Diseases 20(5).

Edgell, Amanda, Anna Lührmann, Seraphine F. Maerz, Jean Lachapelle, Sandra Grahn, Ana Flavia Good God, Martin Lundstedt et al. 2020. Pandemic Backsliding: Democracy During COVID-19 (PanDem), Version 5. Available at: www.v-dem.net/en/ourwork/research-projects/pandemic-backsliding/

El Comercio. 2020a, March 8. "La marcha del 8M en Quito alzó su voz en contra de la violencia y la desigualdad que sufren las mujeres". Retrieved on March, 15, 2021 from: https://www.elcomercio.com/tendencias/sociedad/marcha-8m-alzo-voz-violencia. html

El Comercio. 2020b, July 18. "El Consejo de la Judicatura alerta sobre la falta de recursos para la justiciar" Retrieved on March, 15, 2021 from: https: / /www.elcomercio.com/actualidad/consejo-judicatura-falta-recursos-salario.html.

El Comercio. 2020c, September 29. "28-S: La 'marea verde' exige en calles y plazas de Ecuador la despenalización del aborto para las víctimas de violación". Retrieved on March, 15, 2021 from: https://www.elcomercio.com/tendencias/sociedad/macha-mujeres-quito-despenalizacion-aborto.html

El Universo. 2020, December 31. “Durante la pandemia, la Asamblea Nacional aprobó más leyes con relación al 2019." Retrieved on March, 15, 2021 from: https://www.eluniverso.com/noticias/2020/12/30/nota/9119584/asamblea-nacional-ecuador-aprobacion-leyes-durante-2020/

El Universo, 2021, March 24. "Gabinete en crisis a dos meses que termine el mandato de Lenín Moreno." Retrieved on March, 15, 2021 from: https://www.eluniverso.com/ noticias/politica/gabinete-crisis-dos-meses-termine-mandato-lenin-moreno-nota/

España, Sara. 2020, August 3. Ecuador logra un Alivio de su deuda externa de 1.540 millones de dólares y cinco años de gracia. El País. Retrieved on March, 15, 2021 from: https:/ / elpais.com/economia/2020-08-03/ecuador-logra-un-alivio-de-su-deuda-externa-de1540-millones-de-dolares-y-cinco-anos-de-gracia.html

Espinoza, Gabriela. 2020. "Ecuador: Government Responses to COVID-19". Retrieved on March, 15, 2021 from: https:/ / constitutionnet.org/state-of-emergency.

EVS/WVS (2020). European Values Study and World Values Survey: Joint EVS/WVS 20172021 Dataset (Joint EVS/WVS). GESIS Data Archive, Cologne. ZA7505. Dataset Version 1.0.0. Available at: 10.4232/1.13095.

García, Andrés. 2020, July 9. “A qué responden los siete cambios en el Gabinete Ministerial?” El Comercio. Retrieved on March, 15, 2021 from: https:/ /www.elcomercio.com/actualidad/cambios-gabinete-ministerial-lenin-moreno.html. 
GK. 2020, July 8. “Lenín Moreno anunció cambios en la dirección de seis instituciones". Retrieved on March, 302021 from: https:/ /gk.city/2020/07/09/cambio-gabinete-ecuador/

González-Bustamante, Bastián. 2021. "Evolution and early government responses to COVID-19 in South America". World Development 137: 105-180.

González-Paredes, Santiago, Carol Jara, Leticia Orcés Pareja and Sebastián Umpierrez de Reguero. 2021. "Actitudes populistas, emociones negativas y posición partidaria frente a la inmigración en Ecuador." In Populismo y comportamiento político en Ecuador: incorporando la agenda ideacional, edited by Ríos Rivera, Ingrid and Sebastián Umpierrez de Reguero. Guayaquil: Universidad Casa Grande.

Huertas-Hernández, Sergio. 2021. Asamblea Nacional de Ecuador en tiempos de Pandemia: ¿Qué hacen nuestros legisladores? Clivajes: Boletín de la Asociación Ecuatoriana de Ciencia Política (6):11-15.

Human Rights Watch. 2020. “Ecuador: eventos de 2020” Retrieved on March, 302021 from https://www.hrw.org/es/world-report/2021/country-chapters/377402

IDEA. 2021. "COVID-19 Risk Mitigation Measures during National Elections and Referendums". Retrieved on March, 302021 from https://www.idea.int/news-media/multimedia-reports/global-overview-COVID-19-impact-elections

IMASEN and Fernando Gavilanes, 2019. "Estudio de Opinión Pública". Quito: Investigación Sociológica y de Mercado. Available upon request.

INEC (Instituto Nacional de Estadística y Censo). 2021. Estadísticas por tema. Retrieved on March, 302021 from https:/ / www.ecuadorencifras.gob.ec/

Informa Ecuador. 2021, March 31. "Encuesta: 96\% califica de malo y muy malo el desempeño de Moreno frente a la crisis". Retrieved on March, 302021 from: http:/ /informaec. com/2020/03/31/encuesta-96-califica-de-malo-y-muy-malo-el-desempeno-de-moreno-frente-a-la-crisis-sanitaria/

Inter-Pares Parliaments in Partnership. 2021. "Inter-Pares Parliamentary Data Tracker". Retrieved on March, 302021 from https:/ /www.inter-pares.eu/inter-pares-parliamentary-data-tracker

Inter-Parliamentary Union. 2021. "Country compilation of parliamentary responses to the pandemic". Retrieved on March, 302021 from https://www.ipu.org/country-compilation-parliamentary-responses-pandemic

Labarthe, Sunniva and Marc Saint-Upéry. 2017. "Leninismo versus correísmo: la 'tercera vuelta' en Ecuador." Nueva Sociedad 272: 29-42.

Lührmann, Anna, Marcus Tannenberg and Staffan I. Lindberg. 2018. Regimes of the world (RoW): Opening new avenues for the comparative study of political regimes. Politics and Governance 6(1).

Malo, Gabriela. 2021. "Between Liberal Legislation and Preventive Political Practice: Ecuador's Political Reactions to Venezuelan Forced Migration". International Migration Special Issue Article.

Marsteintredet, Leiv. 2020. "The Vice Presidency and the Problems of Presidential Succession in Latin America: Old and New Challenges to Presidentialism." Política y Gobierno 26(1): 117-137.

Mejía Acosta, Andrés. 2002. Gobernabilidad democrática: sistema electoral, partidos políticos y pugna de poderes en Ecuador (1978-1998). Quito: Konrad Adanauer Stiftung.

Mejía Acosta, Andrés, and John Polga-Hecimovich. 2011. “Coalition Erosion and Presidential Instability in Ecuador". Latin American Politics and Society 53(2): 87-111.

Meléndez, Carlos and Paolo Moncagatta. 2017. "Ecuador: Una Década de Correísmo." Revista de Ciencia Política 37(2): 413-448.

Mélendez, Carlos and Sebastián Umpierrez de Reguero. 2021. Party Members and Activists in Latin America. Oxford Research Encyclopedia of Politics. Available at https://doi. org/10.1093/acrefore/9780190228637.013.1673 
Ministerio de Salud Pública (2021). Situación Nacional por COVID-19. Infografía N³98. Available at: https:/ /www.salud.gob.ec/wp-content/uploads/2021/03/INFOGRAFIA-NACIONALCOVID19-COE-NACIONAL-08h00-3132021.pdf

Montúfar, César. 2016. ¿Vivimos en democracia? Quito: Universidad Andina Simón Bolívar.

National Council for Disability Equality. 2021. "Programa Voto en Casa se cumple con todas las medidas de bioseguridad". Retrieved on March, 302021 from: https:/ /www. consejodiscapacidades.gob.ec/programa-voto-en-casa-se-cumple-con-todas-las-medidas-de-bioseguridad/

Navia, Patricio and Sebastián Umpiérrez de Reguero. 2021. “CREO: el ascenso y los desafíos de consolidación del partido político de derecha emergente en Ecuador (20132021)." Revista Uruguaya de Ciencia Política 30(1): 49-78.

OAS. 2021. "Premilitary Report: OAS Electoral Observation Mission presents its recommendations for the April 11 presidential runoff" Retrieved on March, 302021 from http:/ / www.oas.org/fpdb/press/Preliminary-Report---Ecuador-2021.pdf

Observatorio Legislativo. 2021. "Proyectos de Ley y Leyes Aprovadas". Retrieved on March, 302021 from https://observatoriolegislativo.ec/legislacion/proyectos-de-ley/

Olivares, Alejandro and Pablo Medina. 2020. "La persistente debilidad institucional de Ecuador: Protestas, elecciones y divisiones políticas durante el 2019". Revista de Ciencia Política 40(2): 315-349.

Ortiz, Sara. 2020a, November 26. "La Judicatura exige al CPCCS fundamentos para nulidad parcial o total del concurso de jueces para la Corte Nacional". El Comercio. Retrieved on March, 302021 from https://www.elcomercio.com/actualidad/judicatura-exige-cpccs-fundamentos-pedir.html.

Ortiz, Sara. 2020b, July 5. "El COVID-19 complicó a los juzgados de la Familia". El Comercio. Retrieved on March, 302021 from https:/ / www.elcomercio.com/actualidad/covid19-complico-juzgados-familia-ecuador.html.

Pachano, Simón. 2010. "Ecuador: El nuevo sistema político en funcionamiento". Revista de Ciencia Política 30(2): 297-317.

Palacio, María Gabriela. 2021. “Ecuador's Social Policy Response to Covid-19: Expanding Protection Under High Informality". Universität Bremen, SFB 1342 Globale Entwicklungsdynamiken von Sozialpolitik / CRC 1342 Global Dynamics of Social Policy.

Paredes, Pablo Lucio. 2021. “Salió humo blanco... nuevo presidente electo. 14 cifras económicas y los desafíos del país". Koyuntura Express (23): 1-11.

Puente, Diego. 2021, February 24. "Rehabilitación actualiza cifra de muertos en cárceles del Ecuador; se reportan 79 fallecidos". El Comercio. Retrieved on March, 302021 from https://www.elcomercio.com/actualidad/rehabilitacion-muertes-carceles-amotinamientos-ecuador.html

Rahman, Lutfor. 2016. "Governance and Good governance: A theoretical framework". Public Policy and Administration Research (6)10: 40-50.

Ríos Rivera, Ingrid and Sebastián Umpierrez de Reguero. 2021. Populismo y comportamiento político en Ecuador: incorporando la agenda ideacional. Guayaquil: Universidad Casa Grande.

Ramírez, Jacques, Yoharlis Linares and Emilio Useche. 2019. “Geo Políticas Migratorias, Inserción laboral y Xenofobia: Migrantes Venezolanos en Ecuador". En Después de la Llegada. Realidades de la migración venezolana, editado por Cécile Blouin. Lima: Themis-PUCP.

Rodríguez, Javier. 2020. “¿De qué polarización hablamos?” Vozz data + politics. Retrieved on March, 302021 from http:/ / thevozz.com/de-que-polarizacion-hablamos/

Rosero, Ana. 2020a, December 13. "Aspirantes a jueces de la Corte Nacional fueron notificados con las calificaciones de la prueba teórica". El Comercio. Retrieved on March, 30 2021 from: https://www.elcomercio.com/actualidad/calificaciones-jueces-corte-nacional-judicatura.html. 
Rosero, Ana. 2020b, November 17. “Ocho observaciones arrastra la selección de jueces". El Comercio. Retrieved on March, 302021 from https://www.elcomercio.com/actualidad/observaciones-seleccion-jueces-consejo-judicatura.html

Umpierrez de Reguero, Sebastián. 2016. "Ecuador: entre la democracia y el autoritarismo". In Estados autoritarios latinoamericanos: Ayer, hoy y proyecciones, edited by Olguín Olate, Jorge. Santiago: Universidad Central, 205-219.

Vélez, Roger. 2021, March 13. “72 funcionarios pasaron por el Gabinete de Lenín Moreno desde el 2017". El Comercio. Retrieved on March, 302021 from https:/ / www.elcomercio. com/actualidad/funcionarios-gabinete-lenin-moreno-cambios.html.

Vera Rojas, Sofía and Santiago Llanos-Escobar. 2016. "Ecuador: La democracia después de nueve años de la Revolución Ciudadana" de Rafael Correa". Revista de Ciencia Política 36(1): 145-175.

Vivanco, José Miguel. 2020. "La Corte Constitucional de Ecuador protege derechos durante COVID-19. El estado de emergencia no puede impedir el acceso a la justiciar". Human Rights Watch. Retrieved on March, 302021 from https://www.hrw.org/ es/news/2020/05/04/la-corte-constitucional-de-ecuador-protege-derechos-durante-COVID-19\#

Wolff, Jonas. 2018. Ecuador after Correa: The Struggle over the Citizen Revolution. Revista de Ciencia Política 38(2): 281-302.

Zibell, M. 2020, April 1. “Coronavirus en Ecuador: el drama de Guayaquil, que tiene más muertos por COVID-19 que países enteros y lucha a contrarreloj para darles un entierro digno". BBC Mundo. Retrieved on March, 302021 from https://www.bbc.com/ mundo/noticias-america-latina-52116100

Received: April 26, 2021

Accepted: July 27, 2021

\begin{abstract}
Ana Sofía Castellanos Santamaría is Research Associate in the USAID StrengtheNING Provincial Capacity program for Vietnam at the Mark O. Hatfield School of Government at Portland State University (Oregon, US). She is Ph.D. candidate in the Public Affairs and Policy program at the same university. Her research areas include direct democracy mechanisms, electoral systems, political parties, populism in Latin American democracies, and data governance for the public sector. She has recently published in the International Political Science Review. Email: acastel2@pdx.edu.
\end{abstract}

Régis Dandoy is Professor in Political Science at the Universidad San Francisco de Quito (Ecuador), Visiting Professor at the Université Libre de Bruxelles (Belgium) and Adjunct Researcher at Waseda University (Japan) and the United Nations University (UNU-CRIS). His main research and publishing interests focus on comparative politics, e-democracy, elections, and electronic voting. Recently, he has published in Representation, French Politics, Environmental Politics, Electoral Studies, among others. Email: rdandoy@usfq.edu.ec.

Sebastián Umpierrez de Reguero is Research Associate in the Global Citizenship Observatory (GLOBALCIT) at the European University Institute (Italy) and in the Institute for Research in Social Science at Universidad Diego Portales (Chile). He is dual-PhD Candidate in Political Science at Universidad Diego Portales and in Humanities at Leiden Universiteit (Netherlands). His research areas include party politics, transnational populism and electoral studies, particularly migrant electoral rights, and non-resident citizens' voter turnout. Sebastián has recently published in Representation, Frontiers in Political Science, Oxford Research Encyclopedia of Politics, Latin American Politics and Society, among other regional and international journals. Email: sebastian.umpierrez@eui.eu. 


\section{ANNEX}

Table A1. Vice-presidency rotation (December 2018-February 2021)

\begin{tabular}{|c|c|c|c|}
\hline Vice-president & Period & Party & Functions \\
\hline $\begin{array}{l}\text { Otto } \\
\text { Sonnenholzner } \\
\text { Sper }\end{array}$ & $\begin{array}{l}\text { December } \\
\text { 2018-July } \\
2020\end{array}$ & Independent & $\begin{array}{l}\text { - Coordination of actions of the Sectoral Coun- } \\
\text { cils } \\
\text { - Follow-up of the National Social Dialogue } \\
\text { - Coordination and articulation of the effective } \\
\text { implementation of the } 2030 \text { Agenda for Sus- } \\
\text { tainable Development } \\
\text { - Monitoring of the investment policy and the } \\
\text { implementation of its comprehensive strate- } \\
\text { gies at the international level }\end{array}$ \\
\hline $\begin{array}{l}\text { María Alejandra } \\
\text { Muñoz } \\
\text { Seminario }\end{array}$ & July 2020 & Independent & $\begin{array}{l}\text { - Supervision and coordination of policies for } \\
\text { the simplification and efficiency of foreign } \\
\text { trade to encourage productivity and national } \\
\text { competitiveness } \\
\text { - Monitoring and institutional strengthening of } \\
\text { the National Customs Service } \\
\text { - Coordination and articulation of the effective } \\
\text { implementation of the } 2030 \text { Agenda for Sus- } \\
\text { tainable Development } \\
\text { - Articulation and monitoring of the compre- } \\
\text { hensive strategy for priority care of girls and } \\
\text { boys suffering from chronic or degenerative } \\
\text { diseases } \\
\text { - Simplification and effectiveness of the child } \\
\text { adoption process }\end{array}$ \\
\hline
\end{tabular}

Sources: Borja $(2020 ; 2021)$.

Table A2. Ministries or Executive Agencies changes (February 2020-February 2021)

\begin{tabular}{|c|c|c|c|c|}
\hline $\begin{array}{l}\text { Ministry or } \\
\text { Executive Agency }\end{array}$ & $\begin{array}{l}\text { Minister or } \\
\text { Executive Agent }\end{array}$ & $\begin{array}{l}\text { Assumes office } \\
\text { (month/year) }\end{array}$ & $\begin{array}{l}\begin{array}{l}\text { Leaves office } \\
\text { (month/year) }\end{array} \\
\end{array}$ & Replacement \\
\hline \multirow[t]{2}{*}{$\begin{array}{l}\text { Culture and } \\
\text { Heritage }\end{array}$} & $\begin{array}{l}\text { Juan Fernando } \\
\text { Velasco }\end{array}$ & June 2019 & $\begin{array}{l}\text { September } \\
2020\end{array}$ & Angélica Arias \\
\hline & Angélica Arias & September 2020 & January 2021 & Julio Bueno \\
\hline $\begin{array}{l}\text { Urban Development } \\
\text { and Government }\end{array}$ & $\begin{array}{l}\text { Guido } \\
\text { Macchiavello }\end{array}$ & March 2019 & July 2020 & Julio Recalde \\
\hline $\begin{array}{l}\text { Economy and } \\
\text { Finance }\end{array}$ & Richard Martinez & May 2018 & October 2020 & Muricio Pozo \\
\hline $\begin{array}{l}\text { Energy and } \\
\text { Non-Renewable } \\
\text { Resources }\end{array}$ & $\begin{array}{l}\text { José Agusto } \\
\text { Briones }\end{array}$ & November 2019 & March 2020 & René Ortiz \\
\hline $\begin{array}{l}\text { Economic and Social } \\
\text { Inclusion }\end{array}$ & Ivan Granda & October 2019 & $\begin{array}{l}\text { September } \\
2020\end{array}$ & Vicente Taiano \\
\hline Foreign Affairs & José Valencia & June 2018 & July 2020 & Luis Gallegos \\
\hline
\end{tabular}




\begin{tabular}{|c|c|c|c|c|}
\hline $\begin{array}{l}\text { Ministry or } \\
\text { Executive Agency }\end{array}$ & $\begin{array}{l}\text { Minister or } \\
\text { Executive Agent }\end{array}$ & $\begin{array}{l}\text { Assumes office } \\
\text { (month/year) }\end{array}$ & $\begin{array}{l}\begin{array}{l}\text { Leaves office } \\
\text { (month/year) }\end{array} \\
\end{array}$ & Replacement \\
\hline \multirow{2}{*}{ Public Health } & $\begin{array}{l}\text { Catalina } \\
\text { Andramuño }\end{array}$ & July 2019 & March 2020 & $\begin{array}{l}\text { Juan Carlos } \\
\text { Zeballos }\end{array}$ \\
\hline & $\begin{array}{l}\text { Juan Carlos } \\
\text { Zeballos }\end{array}$ & March 2020 & February 2021 & $\begin{array}{l}\text { Rodolfo } \\
\text { Farfán }\end{array}$ \\
\hline \multirow[t]{2}{*}{ Labor } & Andres Madero & January 2019 & March 2020 & Luis Poveda \\
\hline & Luis Poveda & March 2020 & July 2020 & Andres Ishc \\
\hline \multirow[t]{2}{*}{$\begin{array}{l}\text { Environment and } \\
\text { Water }\end{array}$} & Raúl Ledesma & August 2019 & March 2020 & $\begin{array}{l}\text { Juan } \\
\text { DeHowitt }\end{array}$ \\
\hline & Juan DeHowitt & March 2020 & April 2020 & Paulo Proaño \\
\hline Interior & $\begin{array}{l}\text { Maria Paula } \\
\text { Romo }\end{array}$ & August 2018 & $\begin{array}{l}\text { November } \\
2020\end{array}$ & $\begin{array}{l}\text { Patricio } \\
\text { Pazmiño }\end{array}$ \\
\hline
\end{tabular}

Sources: García (2020); El Universo (2021); Vélez (2021)

Table A3. Approved Laws by the National Assembly of Ecuador (2020)

\begin{tabular}{llc}
\hline Law Approved & $\begin{array}{c}\text { Current } \\
\text { Status }\end{array}$ & $\begin{array}{c}\text { Date of publication or ap- } \\
\text { proval (month-date-year) }\end{array}$ \\
\hline Missing Persons Act & Published & $01-28-20$ \\
Entrepreneurship and Innovation Law & Published & $02-28-20$ \\
Organic Law of School Feeding & Published & $04-21-20$ \\
Law for the Development of Aquaculture & Published & $04-21-20$ \\
Humanitarian Support Law & Published & $06-22-20$ \\
$\begin{array}{l}\text { Public Finance Law } \\
\text { Law for the strengthening of the production, com- } \\
\text { mercialization and industrialization of oil palm }\end{array}$ & Published & $07-24-20$ \\
Law against micro-trafficking & Published & $07-28-20$ \\
$\begin{array}{l}\text { Law on the transfer of real estate due to the closure } \\
\text { of the banking crisis }\end{array}$ & Published & $08-13-20$ \\
$\begin{array}{l}\text { Modernization Law to the Companies Law } \\
\text { Single-use Plastics Reduction Act }\end{array}$ & Published & $12-10-20$ \\
Health Code (total veto of the Executive) & Published & $12-21-20$ \\
\hline
\end{tabular}

Source: El Universo (2020); National Assembly (2021). 
Table A4. Passed Reforms by the National Assembly of Ecuador (2020)

\begin{tabular}{lcc}
\hline Reforms & Current Status & $\begin{array}{c}\text { Date of publication or } \\
\text { approval (month-date-year) }\end{array}$ \\
\hline Reforms to the Public Companies Law & Published & $01-10-20$ \\
Reforms to the Democracy Code & Published & $02-03-20$ \\
$\begin{array}{l}\text { Reforms to the Organic Code of Citizen } \\
\text { Security and Public Order Entities }\end{array}$ & Published & $07-13-20$ \\
Reforms to the Mining Law & Published & $07-28-20$ \\
Reforms to the Social Security Law & Published & $09-01-20$ \\
Reforms to the Law of the Legislative Function & Published & $11-10-20$ \\
Reforms to the Code of the Judicial Function & Published & $12-08-20$ \\
Reforms to the Communication Law & $\begin{array}{c}\text { Approved. Un- } \\
\text { der review by } \\
\text { the Executive }\end{array}$ & $12-10-20$. \\
Reforms to the Human Mobility Law & $\begin{array}{c}\text { Approved. Par- } \\
\text { tial veto by the } \\
\text { Executive }\end{array}$ & $12-03-20$ \\
$\begin{array}{l}\text { Reforms to the COIP in Anti-Corruption } \\
\text { matters }\end{array}$ & $\begin{array}{l}\text { Approved. Un- } \\
\text { der review by } \\
\text { the Executive }\end{array}$ \\
\hline
\end{tabular}

Sources: Asamblea Nacional (2021); Observatorio Legislativo (2021). 
